\title{
Psychological Health Education in Nurseries: Off to a Good Start in the Psychic Development of Children Aged Zero to Eighteen Months
}

\author{
Maria Cristina Machado Kupfer*, Leda Mariza Fischer Bernardino, Maria Eugênia Pesaro, \\ Rosa Maria Marini Mariotto \\ Institute of Psychology, University of São Paulo, São Paulo, Brazil \\ Email: *mckupfer@usp.br
}

Received 30 July 2015; accepted 22 November 2015; published 25 November 2015

Copyright (C 2015 by authors and Scientific Research Publishing Inc.

This work is licensed under the Creative Commons Attribution International License (CC BY).

http://creativecommons.org/licenses/by/4.0/

(c) (i) Open Access

\begin{abstract}
Nurseries are a reality in the lives of present-day babies and modern families must count on them. In Brazil, nurseries are nowadays called Centers for Childhood Education so as to emphasize their role in education. Even though it is necessary to consider childhood education as a valuable tool in psychic or mental health development, efforts in training professionals involved with child care have been few and far between. Psychic development is taken as a dimension in the child's development responsible for the establishment of the subjectivity, as it is conceived by psychoanalysis. Subjectivity supports affective relationships and desires directed at others. It is already known that attention to this dimension in development can significantly reduce the incidence of mental disorders both in childhood and adult life. This study aims to validate a methodology to train teachers and monitor the psychic development of nursery children aged zero to eighteen months. The methodology was applied by psychologists and was based on the IRDI instrument, which is composed by clinical indicators that monitor risks to child development. The indicators were adapted to the nursery environment. Early results indicate that the IRDI Methodology is effective in monitoring and promoting mental health in early childhood.
\end{abstract}

\section{Keywords}

Psychoanalysis, Childhood Education, Risk Indicators, Child Development

${ }^{*}$ Corresponding author.

How to cite this paper: Kupfer, M. C. M., Bernardino, L. M. F., Pesaro, M. E., \& Mariotto, R. M. M. (2015). Psychological Health Education in Nurseries: Off to a Good Start in the Psychic Development of Children Aged Zero to Eighteen Months. Creative Education, 6, 2197-2204. http://dx.doi.org/10.4236/ce.2015.620225 


\section{Introduction}

Nurseries are a reality in the lives of present-day babies: modern families, especially those living in large urban centers, must count on them (Ministry of Planning, 2010). Therefore, one cannot ignore nurseries' responsibilities in the psychic and mental development of children.

In the early $20^{\text {th }}$ Century, Brazilian institutions for the education of children carried, for the most part, the marks of their historical connections to social assistance work and took their mission to be one of a solely charitable nature. However, since the beginning of the $21^{\text {st }}$ Century, public administrators' revised guidelines have pushed schools past their charitable origins and towards the recognition of their educational purpose. Since then, their effort has been aimed at turning nurseries into child education centers and offering children, from the very beginning, not only a place where they will be cared for, but also educated. Therefore, nurseries' current objectives are nowadays clearly pedagogical. Caretakers are now redefined as teachers, and they work in nursery “classes" open to newborn babies (Campos, Rosemberg, \& Faria, 1995).

Nevertheless, child education is rarely seen as a mental health tool, or, in other words, as an aid in psychic development. Babies are still thought of as having relatively unimportant subjective lives and requiring mostly physical care and motor and cognitive stimulation, when, in fact, caretakers' actions in a child's first year are decisive in their overall development, and even more specially so in their psychic life. A lot of research and clinical observation in several fields in psychology reveal that the ability to organize one's psyche is not innate, it "depends on assistance from those responsible for the child, and it is by means of early relational exchanges with relevant adults that the baby will record memories in their developing psyches" (Jerusalinsky et al., 2015: p. 409). Furthermore, while there has been great progress in improving teachers' training programs in regards to children's intellectual and psychomotor development, advances in training in the promotion of psychic development has been of very little significance (Oliveira, 2002).

Psychic development is taken as a dimension in one's development responsible for establishing subjective experiences that support affective relationships as well as desires directed at others. This subjectivity, as it is conceived by psychoanalysis, is established very early on and it dictates the directions of a child's relationships throughout their existence. In addition, it is essential for shaping one's personality, as well as for the creation of psychic defenses against anxiety, a well-known cause for much emotional instability in children. According to Winnicott (2012), for example, "a physically sane child of normal, or even supranormal intellect, can be very far off from normal in regards to personality as a whole” (p. 140). According to the famed pediatrician and psychoanalyst, who was always concerned with promoting mental health since early childhood, "what we want to know is if a child's personality is developing normally and if their character is becoming stronger in a healthy manner" (Winnicott, 2012: p. 141).

It is already known that attention to this stage in development can significantly reduce the incidence of mental disorders both in early and adult life. Some recent research has shown that early interventions aimed at this perspective can avoid lengthy periods of suffering and treatment (Laznik, 2000; Crespin \& Parlato-Oliveira, 2015; Guedenay, 2007). However, current efforts in promoting health and education during early childhood have yet to take into account this conception of psychic development.

The concern for today's children's future psychic development is not without merit. In fact, there has been a significant increase in childhood mental disorders in present times. The incidence and epidemiological prevalence of developmental and mental disorders during childhood in most developing countries are still largely unknown. Several epidemiological studies suggest rates between $9 \%$ and $16 \%$ (Bird, 1996). According to a review of epidemiological studies published in Brazil between 1980 and 2006 (Couto et al., 2008), prevalence rates for mental disorders in children, when informed by parents or the child, vary from $12.6 \%$ to $35.2 \%$. This rate varied between $7 \%$ and $12.7 \%$ in studies based on a diagnostic interview (Fleitlich \& Goodman, 2004).

By any definition, education offered in nurseries obviously fails to clearly include a concern for psychic wellbeing. While this probably results from a lack of mainstream interest, there are authors striving to include this dimension into a working definition of education (Kupfer, 2012; Lajonquière, 2010; Voltolini, 2011). According to them, education implies the transmission of symbolic marks that allow the child to enjoy not only a role as a simple maternal language speaker or reproducer in the field of language but also the possibility of expressing themselves about their inner world, even in an unconscious way, by means of drawings, for example, in the future. As such, "well educated" children will be closer to guiding themselves based on their desires whilst on their journey through cognition, even if they fail to realize that this guidance is an effect of their own uncons- 
cious world (Kupfer, Bernardino, \& Mariotto, 2014). However, this enlarged meaning of education is still largely absent from the medical and pedagogical discourse that applies to nurseries. The challenge, therefore, is to include children's subjective development as a specific concern during the nursery stage. We know, above all, that this will allow concrete efforts in the prevention of mental disorders.

To allow for this change, training must be improved to prepare teachers to expand their function and to create a dialogue between caring for and educating small children with the goal of promoting mental health since early childhood.

To answer the challenge of introducing the view of psychic development in nursery education, something still seen as uncommon, our research aims to validate a procedure for monitoring psychic development in child education institutions. Procedures were carried out by psychologists and evaluated in accordance with clinical indicators for early detection of developmental problems. Monitoring is based on an adaptation, for the nursery environment, of the IRDI instrument (Clinical Indicators for Risks in Child Development, abbreviated as IRDI according to the acronym in Portuguese), as described in the following section.

\subsection{The IRDI Instrument}

IRDI was originally conceived to monitor psychic development in babies during regular pediatricians' appointments. It consists of 31 clinical indicators of psychic risk or developmental problems noticeable during the first 18 months of a child's life. The instrument was validated by research conducted between 2000 and 2008 at the Institute of Psychology at the University of São Paulo (Kupfer et al., 2010), carried out at the request of the Brazilian Ministry of Health. Funds were provided by FAPESP (São Paulo Research Foundation) under its Thematic Projects.

IRDI is currently part of the Care Guidelines for the Rehabilitation of Persons with Autism Spectrum Disorders (since 2013) and is used as an early screening instrument for developmental problems (Brazil, 2013).

Different professionals occupied with early childhood have been using IRDI to guide their interventions. This is based on research results that showed it is possible to promote and monitor babies' psychic development outside the family environment with IRDIs used to train health care professionals in the Brazilian Sistema Único de Saúde (Lerner et al., 2013) ${ }^{1}$.

\subsection{IRDI in Nurseries}

Based on its successful use as a developmental monitoring tool by health care professionals, this paper proposes to test an application of IRDI as an intervention-guiding tool in early childhood education so as to allow teachers to monitor and promote psychic development in children aged zero to eighteen months.

The instrument was adapted, substituting the mother for the nursery teacher, based on the premise that the latter continues much of the maternal work when it comes to psychic development (Mariotto, 2009; Crespin, 2006). Table 1 shows adapted indicators for the nursery environment.

\section{Method}

364 children of 26 nurseries in the Brazilian cities of São Paulo and Curitiba were monitored for 9 months. 107 teachers took part in the study, which lasted from 2012 to 2013 and was also sponsored by FAPESP. 27 researchers were responsible for weekly visits to nurseries for monitoring over 9 months. They would note the presence or absence of the IRDIs. Absent IRDIs are an indication of possible obstacles to a child's psychic constitution. Researchers would regularly engage teachers in these observations, with a view to focusing their attention on babies with absent indicators. This intervention consisted of discussions regarding absent indicators and suggestions of a course of action to help them regain interaction with the baby, as well as interactions between researchers and babies to allow the teacher to repeat the interaction model with the baby on other occasions during the week.

The frequency with which absent indicators became present in the nursery study was compared to the frequency with which they became present in the IRDI validation study. Changes in indicators cannot be attributed to "natural" development. If they are absent at a given age range, this shows that an expected psychic process has failed to occur, and therefore requires an intervention in the parent-baby pair in order for them to become

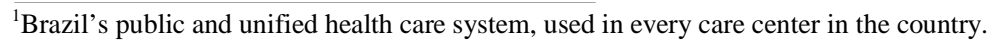


Table 1. IRDI adapted to nursery teachers.

\begin{tabular}{|c|c|}
\hline Age in months & Indicators \\
\hline 0 to 4 incomplete months: & $\begin{array}{l}\text { 1) When the child cries or screams, the teacher knows what the child wants. } \\
\text { 2) The teacher talks to the child in a style that is particularly addressed to the child (motherese). } \\
\text { 3) The child responds to motherese. } \\
\text { 4) The teacher proposes something to the child and waits for his/her response. } \\
\text { 5) Teacher and child exchange eye contact. }\end{array}$ \\
\hline 4 to 8 incomplete months: & $\begin{array}{l}\text { 6) The child responds to nursery routines } \\
\text { 7) The child uses different signs to express different needs. } \\
\text { 8) The child demands the teacher's attention and waits some time for her response. } \\
\text { 9) The teacher talks to the child using short sentences to address him/her. } \\
\text { 10) The child responds (sound, vocals) when the teacher or somebody else addresses him/her. } \\
\text { 11) The child actively seeks contact with the teacher's eyes. } \\
\text { 12) The teacher supports the child's initiatives without stopping their efforts. } \\
\text { 13) The child asks for help from others without remaining passive. }\end{array}$ \\
\hline 8 to 12 incomplete months: & $\begin{array}{l}\text { 14) The teacher understands that some demands from the child may be a way to call her attention. } \\
\text { 15) During body care, the child actively attempts to play loving games with the teacher. } \\
\text { 16) The child shows that they like or dislike something. } \\
\text { 17) Teacher and child share a private language. } \\
\text { 18) The child feels ill at ease with unknown people. } \\
\text { 19) The child has favorite objects. } \\
\text { 20) The child makes playful movements and faces. } \\
\text { 21) The child seeks the adult's look of approval. } \\
\text { 22) The child accepts semi-solid and varied foods. }\end{array}$ \\
\hline 12 to 18 months: & $\begin{array}{l}\text { 23) The teacher alternates between collective moments and moments dedicated exclusively to the child. } \\
\text { 24) The child endures the teacher's brief absences well while reacting to longer absences. } \\
\text { 25) The teacher offers toys as alternatives to the child's interest in the teacher's body. } \\
\text { 26) The teacher no longer feels compelled to meet all of the child's demands. } \\
\text { 27) The child looks curiously at things that interest the teacher. } \\
\text { 28) The child likes to play with objects used by the teacher. } \\
\text { 29) The teacher starts to ask the child to say what they want, not being satisfied with gestures only. } \\
\text { 30) The teacher establishes small behavioral rules for the child. } \\
\text { 31) The child differentiates between objects belonging to the teacher and to him/her. }\end{array}$ \\
\hline
\end{tabular}

present. In Group 1, during the validation study, this transformation may have occurred due to a non-systematic intervention by the pediatrician; however, these interventions were infrequent and were not specifically targeted by the study. In Group 2, however, the intervention was a specific aim of the study. The study sought to demonstrate that IRDI guided interventions allow a child to resume an absent or interrupted psychic process during the time they are in nursery.

Validation study Group 1 (Control Group) included 723 children aged 0 - 18 months whose IRDI was scored between 2000 and 2002. The pediatricians were responsible for the score of the IRDIs and were supervised by the researchers. Group 2 (Case Group) included 374 children aged 0 - 18 months monitored in nurseries in 2012 and 2013. The IRDI scores were taken by the researchers.

\section{Results}

The data was analyzed using the chi-square test.

Table 2 shows a comparison between IRDI indicators for groups 1 and 2, in regards to changes in each indicator from absent to present. Results show that, with the exception of indicator 31, there was a significant difference between Groups 1 and 2 for the remaining IRDI indicators. The proportion of changes in absent to present indicators was significantly greater in Group 2 than in Group 1.

Results indicate that IRDI is an effective model for intervention in promoting mental health during early infancy. If one considers the absence of systematic interventions in the first IRDI study it seems valid to assume that guided interventions with the teachers were significant and may have been responsible for a "presentification" of IRDIs in children under their care. 
Table 2. Comparison in IRDI indicators for Groups 1 and 2.

\begin{tabular}{|c|c|c|c|c|c|c|c|c|c|}
\hline & \multicolumn{4}{|c|}{ Group 1} & \multicolumn{4}{|c|}{ Group 2} & \multirow{2}{*}{ Sig*. } \\
\hline & A-A & P-P & A-P & P-A & A-A & P-P & A-P & P-A & \\
\hline Indicator 1 & 0.0 & 98.9 & 0.0 & 1.2 & 1.7 & 83.6 & 14.7 & 0.0 & $<0.001$ \\
\hline Indicator 2 & 0.0 & 98.6 & 0.7 & 0.7 & 5.0 & 82.3 & 9.4 & 3.3 & $<0.001$ \\
\hline Indicator 3 & 0.0 & 98.6 & 1.0 & 0.5 & 1.6 & 85.2 & 10.4 & 2.0 & $<0.001$ \\
\hline Indicator 4 & 0.0 & 97.3 & 1.0 & 1.7 & 7.7 & 70.5 & 21.8 & 0.0 & $<0.001$ \\
\hline Indicator 5 & 0.0 & 98.8 & 0.2 & 0.9 & 1.4 & 89.6 & 8.5 & 0.5 & $<0.001$ \\
\hline Indicator 6 & 0.0 & 97.4 & 0.7 & 1.9 & 2.3 & 82.7 & 14.6 & 0.4 & $<0.001$ \\
\hline Indicator 7 & 0.0 & 97.7 & 0.7 & 1.6 & 6.6 & 75.5 & 17.5 & 0.0 & $<0.001$ \\
\hline Indicator 8 & 0.0 & 96.4 & 1.5 & 2.2 & 11.9 & 66.1 & 21.4 & 0.6 & $<0.001$ \\
\hline Indicator 9 & 0.0 & 98.6 & 0.5 & 0.9 & 4.8 & 89.1 & 5.6 & 0.4 & $<0.001$ \\
\hline Indicator 10 & 0.0 & 99.1 & 0.0 & 0.9 & 2.1 & 90.7 & 6.8 & 0.4 & $<0.001$ \\
\hline Indicator 11 & 0.0 & 98.3 & 0.7 & 0.9 & 3.6 & 87.8 & 8.6 & 0.0 & $<0.001$ \\
\hline Indicator 12 & 0.0 & 97.0 & 0.5 & 2.5 & 16.7 & 72.0 & 10.6 & 0.8 & $<0.001$ \\
\hline Indicator 13 & 0.0 & 94.9 & 1.0 & 4.1 & 9.6 & 69.1 & 20.2 & 1.1 & $<0.001$ \\
\hline Indicator 14 & 0.0 & 97.2 & 1.2 & 1.6 & 5.1 & 83.1 & 10.3 & 1.5 & $<0.001$ \\
\hline Indicator 15 & 0.0 & 97.1 & 1.7 & 1.2 & 40.1 & 42.0 & 13.6 & 3.7 & $<0.001$ \\
\hline Indicator 16 & 0.0 & 99.1 & 0.7 & 0.2 & 2.6 & 90.3 & 6.5 & 0.6 & $<0.001$ \\
\hline Indicator 17 & 0.0 & 95.3 & 2.4 & 2.4 & 68.0 & 15.2 & 14.4 & 2.4 & $<0.001$ \\
\hline Indicator 18 & 0.0 & 89.3 & 5.1 & 5.6 & 46.9 & 32.0 & 13.1 & 8.0 & $<0.001$ \\
\hline Indicator 19 & 0.0 & 94.6 & 2.6 & 2.8 & 58.3 & 25.0 & 14.6 & 2.1 & $<0.001$ \\
\hline Indicator 20 & 0.0 & 98.1 & 0.7 & 1.2 & 7.7 & 78.2 & 12.2 & 2.1 & $<0.001$ \\
\hline Indicator 21 & 0.0 & 97.9 & 0.5 & 1.7 & 7.3 & 86.3 & 6.5 & 0.0 & $<0.001$ \\
\hline Indicator 22 & 0.0 & 98.4 & 0.2 & 1.4 & 1.1 & 90.8 & 7.5 & 0.6 & $<0.001$ \\
\hline Indicator 23 & 0.0 & 98.2 & 0.0 & 1.8 & 3.0 & 92.5 & 1.5 & 3.0 & $<0.001$ \\
\hline Indicator 24 & 0.0 & 97.7 & 0.0 & 2.3 & 12.9 & 58.1 & 19.4 & 9.7 & $<0.001$ \\
\hline Indicator 25 & 0.0 & 97.7 & 0.2 & 2.1 & 18.4 & 68.8 & 5.3 & 7.9 & $<0.001$ \\
\hline Indicator 26 & 0.0 & 97.7 & 0.0 & 3.3 & 0.0 & 94.2 & 5.8 & 0.0 & $<0.001$ \\
\hline Indicator 27 & 0.0 & 97.4 & 0.0 & 2.6 & 2.0 & 91.8 & 4.1 & 2.0 & $<0.001$ \\
\hline Indicator 28 & 0.0 & 94.1 & 0.0 & 5.9 & 2.1 & 93.6 & 2.1 & 2.1 & $<0.001$ \\
\hline Indicator 29 & 0.0 & 98.6 & 0.0 & 1.4 & 82.4 & 2.9 & 14.7 & 0.0 & $<0.001$ \\
\hline Indicator 30 & 0.0 & 92.5 & 0.0 & 7.5 & 0.0 & 100.0 & 0.0 & 0.0 & 0.045 \\
\hline Indicator 31 & 0.0 & 87.7 & 14.3 & 0.0 & 0.0 & 85.7 & 14.3 & 0.0 & 1.000 \\
\hline
\end{tabular}

Note: scores are expressed as percentages; Labels: ${ }^{*}$ Chi-square test; A-A = Absent Indicator that remains Absent; P-P = Present Indicador that remains Present; A-P = Absent Indicator that changes to Present; P-A = Present Indicator that changes to Absent. 
To better appreciate the results, it is important to observe that changes in absent indicators do not easily result solely from interventions aimed at improving the teachers' training. The indicators monitor the baby's reaction, which serves as a litmus test: one can only say an interaction has changed in quality when the baby shows they have somehow been affected by the changed interaction. Therefore, what changes in indicators from absent to present show are real transformations in interactions.

The reduction in absent risk indicators is a significant finding, since it suggests that offering practical training to nursery teachers is very important to allow them to consider courses of action which take babies' subjectivities into account. Conversely, this training tends to be insufficient if it is limited to theoretical information. It can be said that this practical training was essential to successfully employing IRDI as a guide for action and as a reference for discussions regarding childcare.

Tocchio (2013) reached similar results in a study evaluating the effects of training nurses to identify issues relating to babies' psychic development during routine appointments. They also reported a rise in frequency in groups of trained nurses of references to patients' psychological aspects.

Morais et al. (2015) further showed the greater permanence of training with pediatricians when indicators are mostly related to the paternal function. Also according to the study, pediatricians claimed the training was responsible for an increased satisfaction in treating babies. This is key, given that both teachers and pediatricians need to be psychically present when interacting with babies. Training them to stimulate the babies is not enough: they must be emotionally involved in the task, so as to truly attract the babies' attention. This involvement is stimulated by use of IRDIs and the instrument's ability to emphasize developmental aspects that can be difficult to observe in everyday life. If there is no involvement, it is highly unlikely that these professionals can either promote children's psychic development or help parents to do so.

It is also important to discuss the relative insignificance of results for indicator 31. It is possible to hypothesize that indicator 31 is relatively weak to assess psychic development in nurseries, since this indicator is mostly associated with the family environment. Its original formulation is: The child differentiates between objects belonging to their mother, their father, and to them, and its modified version for the nurseries reads: The child differentiates between objects belonging to the teacher and to them. However, its strength in regards to assessing psychic development lies chiefly in the perceptions children have of the differences between their parents and themselves. In nursery, differences between children and adults are somewhat diluted between a number of adults and children, which may account for the small differences regarding this indicator between Group 1 and Group 2.

One must further observe that certain differences between the groups do not allow us to reach definitive conclusions. Distribution of children in age groups in both samples is not homogeneous: Group 2, for example, shows more markings in the third and fourth ranges. However, the differences in transformations between the Groups can be clearly seen, even considering that the children's age distribution introduces a difference between the samples.

It remains to be seen whether these transformations are long lasting and contribute in improving the children's psychic development towards an effective state of mental or psychological health. For that reason, this study will be extended to compare children's IRDI results at age 3 with their results from ages zero to eighteen months.

\section{Conclusions}

Even so, it is already possible to note how important it is to monitor the teachers as they relate to the babies. Current results support our claim that teacher training is quite effective at modifying teacher-children relationships and improving babies' mental health. In this sense, we can say that nursery educators can be mental health agents. Furthermore, it is also possible to claim that the environment in which early childhood education takes place is very conducive to the early detection of risks to a child's psychic development. Therefore, babies at risk can receive improved and better-directed care, allowing the situation to rapidly revert to a recovery of standard development.

Finally, some implications of this study can be pointed out. If Public Policy for Early Childhood Education takes these results into account, better conditions for a good start for the children in the nurseries will be set, such as giving more time for the teachers to discuss about their relationship to the children with professionals visiting the schools, or more time and opportunities for them to be attentive to the mental health of the children 
in the nurseries.

\section{Acknowledgements}

We would like to thank FAPESP and CNPq for their support and research funding, and the group of researchers who carried out the research, who dedicated themselves to going to the nurseries and collected data that turned out to be so significant.

\section{References}

Brazil. Ministry of Health. Health Secretariat. Department of Strategic Programmatic Actions (2013). Care Guidelines for the Rehabilitation of Persons with Autism Spectrum Disorders. (Diretrizes de atenção à reabilitação da pessoa com transtornos do espectro do autismo). Brasília: Ministry of Health.

Campos, M. M., Rosemberg, F., \& Ferreira, I. M. (1995). Nurseries and Pre-Schools in Brazil. (Creches e pré-escolas no Brasil) (2nd. ed.). São Paulo: Cortez.

Couto, M. C. V., Duarte, C. S., \& Delgado, P. G. G. (2008). Child Mental Health and Public Health in Brazil: Current Situation and Challenges. Brazilian Journal of Psychiatry, 30, 390-398.

Crespin, G. (2006). Words of Littleones. (Paroles de tout-petits) (1st ed.). Listening to Nursery Children (À l'écoute des enfants en crèche). Paris: Albin Michel.

Crespin, G., \& Parlato-Oliveira, E. (2015). Préaut. (Project). In A. Jerusalinsky (Ed.), Autism Dossier. (Dossiê autism) (pp. 436-455). São Paulo: Instituto Langage.

Fleitlich, B. W., \& Goodman, R. (2004). Epidemiology. (Epidemiologia). Brazilian Journal of Psychiatry, 22, 2-6.

Guedenay, A., Mintz, A. S., \& Dugravier, R. (2007). Developmental Risks in Babies from Birth to 18 Months. (Risques développementaux chez le nourrisson de la naissance à 18 mois). Psychiatry/Pedopsychiatry, 17, 195-200.

Jerusalinsky, A. N. et al. (2015). Babies at Risk of Autism and Psychoanalysts’ Resources for Helping Them. (Bebês em risco de autismo e os recursos do psicanalista para ajudá-los). In: A. Jerusalinsky (Ed.), Autism Dossier (pp. 407-415). São Paulo: Instituto Langage.

Kupfer, M. C. M., Bernardino, L. M. F., \& Mariotto, R. M. M. (Eds.) (2014). From Baby to Subject: The IRDI Methodology in Nurseries (De bebê a sujeito: A metodologia IRDI nas creches). São Paulo: Escuta/Fapesp, 304 p.

Kupfer, M. C. M., Jerusalinsky, A. N., Bernardino, L. M. F., Wanderley, D. R., Barbosa, P. S., Molina, S. E. et al. (2010). Predictive Value of Clinical Risk Indicators in Child Development: Final Results of a Study Based on Psychoanalytic Theory. Latin American Journal of Basic Psychopathology, 13, 31-52. http://www.scielo.br/scielo.php?script=sci_arttext\&pid=S1415-47142010000100003\&lng=en\&tlng=en http://dx.doi.org/10.1590/s1415-47142010000100003

Kupfer, M. C., Bernardino, L. M. F., Mariotto, R. M. M., Pesaro, M. E., de Lajonquière, L., Voltolini, R., \& Machado, A. M. (2012). IRDI Methodology: Prevention Actions in Infancy (Metodologia IRDI: Umaação de prevençãona primeira infância). In M. C. Kupfer, L. F. Bernardino, \& R. M. M. Mariotto (Eds.), Psychoanalysis and Prevention Actions in Infancy (Psicanálise e ações de prevenção na primeira infância) (pp. 129-143). São Paulo: Escuta/Fapesp.

Lajonquière, L. (2010). Childhood Figures: Psychoanalysis in Children’s Daily Lives (Figuras do infantil: A psicanálise na vida cotidiana com as crianças) (p. 272). Petrópolis: Vozes.

Laznik, M. C. (2000). The Voice as the Oral Drive’s First Object (A voz como primeiro objeto da pulsão oral). Estilos da Clinica. Revista sobre a Infância com Problemas. (Styles of Practice. Journal of Childhood Problems), 5, 80-93.

Lerner, R., di Paolo, A. F., Campana, N. T. C., de Morais, A. S., Tocchio, A. B., \& da Silva, R. R. F. (2013). Psychology at the Crossroads between the Collective and the Psychic: The Construction of a Public Health Policy of Development Care (A Psicologia na articulação entre os âmbitos coletivo e psíquico: Construção de uma política pública em saúde de cuidado com o desenvolvimento). Psychology: Science and Profession, 33, 100-111. http://www.scielo.br/scielo.php?script=sci_arttext\&pid=S1414-98932013000500011\&lng=en\&tlng=pt

Mariotto, R. M. M. (2009). Caretaking, Education and Prevention: The Role of Nurseries in Babies' Self-Formation (Cuidar, educar e prevenir: As funções da creche na subjetivação de bebês). São Paulo: Escuta.

Ministry of Planning, Budget, and Management. Brazilian Institute of Geography and Statistics (2010). A Synthesis of Social Indicators: An Analysis of the Living Conditions of the Brazilian Population (Síntese de Indicadores sociais: Uma análise das condições de vida da população brasileira ). Studies and Research—Demographic and Socioeconomic Information, Rio de Janeiro: IBGE.

Morais, A. S., Bronzatto, E. M. K., Lerner, R., \& Kupfer, M. C. M. (2015). Effects of Pediatric Training for Detecting Signs of Developmental Problems. Psychology: Science and Profession, 35, 359-373. 
http://www.scielo.br/scielo.php?script=sci_arttext\&pid=S1414-98932015000200359\&lng=en\&tlng=en http://dx.doi.org/10.1590/1982-370300252014

Oliveira, Z. M. R. (2002). Child Education: Foundation and Methods (Educação Infantil: Fundamentos e métodos). São Paulo: Cortez.

Tocchio, A. B. (2013). Continuous Training of Nursing Professionals in Basic Health Based on Clinical Indicators of Risk to Child Development (Educação permanente de profissionais de enfermagem da atenção básica à saúde a partir de indic adores clínicos de risco para o desenvolvimento infantil). Master’s Thesis, São Paulo: University of São Paulo.

Voltolini, R. (2011). Education and Psychoanalysis (Educação e psicanálise). Rio de Janeiro: Zahar, 84 p.

Winnicott, D. W. (2012). The Child, the Family and the Outside World (6th ed.). Rio de Janeiro: LTC, 270 p. 